\title{
The Discretionary Accrual in the Financial Statement of a Public Company in Indonesia: A Literature Review
}

\author{
Muhammad Haykal
}

Faculty of Economic and Business, University of Sumatera, Utara Medan, Indonesia

\begin{abstract}
Purpose - Previous studies distinguish revenue management based on discretionary accruals; the research of studies is to investigate the factors that affect the finance manager at the discretionary accrual in General financial information statement.

Design/Methodology/Approach - Literature review models used in research aimed at detecting any company that performs the company's discretion to fulfill the accrual of interests internally. This research study also discusses the relationship between earnings and discretionary manager behavior.

Findings - The researcher wants to re-examine the hypothesis of market efficiency on Indonesia's capital market. The current company information technology uses greatly influences worldwide investor interest to invest on Indonesian's capital market. Emerging Indonesia Capital market status becomes very interesting to be studied.

Originality/Value - It also presented the shortcomings of current research and the trends for future study in capital market.
\end{abstract}

Keywords Discretionary accrual, financial manager, investors, financial statement

All papers within this proceedings volume have been peer reviewed by the scientific committee of the Malikussaleh International Conference on Multidisciplinary Studies (MICoMS 2017).

\section{Introduction}

The capital market is an activity related to the public offering and securities trading, the public company relating to the securities publishing, as well as the securities-related institutions and professions. Capital markets provide a wide range of investments to investors other than other investment alternatives such as saving in banks, buying gold, insurance, and land and buildings. In earnings, management research found the use of discretionary accruals to change the reported income between two fiscal periods. Earnings have two components: cash flow from operating activities and total accruals. Total accruals are assessments and management estimates of cash flows to make accounting profit reflect

(C) Muhammad Haykal. Published in the Emerald Reach Proceedings Series. Published by Emerald Publishing Limited. This article is published under the Creative Commons Attribution (CC BY 4.0) licence. Anyone may reproduce, distribute, translate and create derivative works of this article (for both commercial and non-commercial purposes), subject to full attribution to the original publication and authors. The full terms of this licence may be seen at http://creativecommons.org/licences/by/4.0/ legalcode

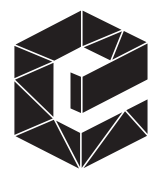

Emerald Reach Proceedings Series Vol. 1 Emerald Publishing Limited DOI $10.1108 / 978-1-78756-793-1-00047$ 
Proceedings of MICoMS 2017

596 better economic performance, total accruals resulting from the amount of accrual discretion and non-discretionary accruals (Demirkan et al., 2012).

To detect the presence of accrual discretion, we need a model specification to calculate the accrual discretion. The model ranges from simple, where total accrual is used as an accrual discretionary measure of a relatively sophisticated variable (regression), which describes accruals to discretion and non-discretionary components. Previous research has found evidence that accrual accounting has been performed in various forms. For example, research has found the existence of executive incentives to manipulate earnings in an attempt to meet the thresholds laid down in their bonus scheme contracts (Healy, 1985). Indicate that managers will manipulate earnings to reach such threshold as positive earnings, positive performance of previous period, and expectation analysis. The efficient contracting perspective of accounting choices provides evidence consistent with the idea that managers exercise accounting discretion to increase their compensation, avoid debt covenants violation, and reduce the chance of exposure to political or governmental intrusions into their business's affairs. Management may also tend to smooth the reported earnings in an attempt to meet investors' expectations of future cash flows.

In efficient marketing, theory is mentioned that stock prices are a reflection of all available information in the market (Bonazzi and Islam, 2007), and the result of competition among rational investors with a level of expectation free of sentiment and only related to factors fundamental in the analysis by investors. The results of the study conducted by Frugier et al. (2016) found that have a negative and insignificant effect on future profits, especially short-term stock returns during normal company situations, and a surprisingly significant positive effect during the crisis. The impact of sentiment is more pronounced on firms with more uncertain costs, and discovery of accrual discretion is associated with capital market incentives (Frugier et al., 2016).

\section{Research methods}

\subsection{Literature review about discretionary accrual}

2.1.1. Executive bonus plans hypothesis Dechow et al. (2012) explained that the lower persistence of accruals can be grouped into two categories: the diminishing marginal returns embedded in new investment and accounting distortions. Baber and Fairfield (1991) showed the diminishing marginal returns imply that for high-profit companies, returns on the real investment acquired in the current period will be lower in the next period due to competition. This will drag down the average return for the company's real investments towards the long-term mean return. On the other hand, investments generating lower returns in the current period will be replaced by investments with better returns in the current or future period. This will drive up the average return towards the long-term mean.

Several studies documents evidence supporting the view of managers manipulates earnings when their potential compensation is linked with the value of shares and options. For example, Agnes Cheng and Reitenga (2009) demonstrate that the sensitivity of managers' wealth to the short-term stock price may motivate managers with high stockbased compensations and stock equity to manage earnings. More specifically, they emphasize that those managers are more likely to report earnings that meet or beat analysts' forecasts and sell more shares in the year after earnings announcement. Bergstresser and Philippon (2006) also found a significant association between equity incentives and abnormal accruals. 
Francis et al. (2005) in relevant study provided evidence on the impact of accounting quail on the interest cost of debt in Barth et al. (2001) focus on the aggregate firm level interest cost of outstanding debt and find that interest costs for lowest accounting quality firms are higher 126 basis point relative to firms with the highest accounting quality. While their study provides an interesting first view on the role of accounting quality in debt markets, it leaves several unanswered questions. Unlike equity, debt contracts have multiple contract terms (interest, maturity, and collateral), and the role of accounting quality in the setting of multiple contract terms is not well understood. Lenders can fine tune the risk-return relationship with the borrower by setting terms for not only the interest cost but also the maturity term and collateral required in the contract.

Since debt agreements depend on accounting numbers reported on financial statements, managers have the opportunity to choose accounting methods that allow them to avoid violating these agreements. These contracts often include restrictive covenants that limit potential conflicts interest between firms' debt holders and shareholders, as well as restricting managers' scope to engage in activities that may adversely affect the debt holders' wealth. These include limiting the ability of management to issue new debt and giving the debt holders the right to demand early repayment of the debt when certain accounting numbers are not maintained (Kamarudin and Ismail, 2014).

\subsection{Political costs hypothesis}

Since large firms are usually more politically visible, abnormally large increases in reported earnings may be used as an indicator of a monopoly, or used as an excuse for political or governmental intrusions into their business's affairs (Khan and Watts, 2009). Thus, managers of large firms are expected to have greater incentives to make accounting choices that reduce the likelihood of these political costs being incurred. It found that firms use income-decreasing discretionary accruals in industries applying to the United States International Trade Commission for import relief, and in firms under investigation for antitrust dealings during the year of the investigation. Similar results are found in the cable television industry and in chemical firms exposed to the Superfund laws (Khalil and Simon, 2014).

\subsection{Earnings smoothing hypotheses}

Earnings smoothing have been the subject of concern with regulatory and accounting studies alike. Managers may tend to use accounting discretion afforded by accounting standards to reduce the fluctuations of earnings in an attempt to report a less variable earnings stream and to show that the company has less risk. Managers can do so by, for example, understating earnings in years of high performance in order to create reserves for future periods. However, it is found that managers may engage in earnings smoothing even if managerial compensation is not tied with earnings (Khalil and Simon, 2014).

\section{Relationship Between Discretionary Accrual And Opportunistic Manager}

There are several references that explain the impact of discretionary accrual on opportunistic manager. It can be seen in Table 1.

\subsection{The antecedents of discretionary accrual}

Variable Discretionary Accrual not comes about easily but is formed from several subvariables. Regarding above, no model can perfectly identify the benchmark level of accruals 
Proceedings of MICoMS 2017

\section{8}

expected as a response to the economics' conditions. Such a benchmark is needed to measure the discretionary component of accruals that is due to special incentives to manage earnings. There is much debate as to the success of the alternative proxies. For more details, see Table 2.

\subsection{Suggestions for the Future Studies}

Abnormal accruals have been the focus on much empirical research in accounting. Almost more than one hundred papers used "abnormal" accruals generated from an accruals' model as a measure of earnings quality. According to Dechow (1994), discretionary accruals often provide managers the opportunities to manipulate earnings due to the flexibility available. To detect earnings management, Healy (1985) was the first to introduce discretionary accruals. It was presumed discretionary accruals fall subject to managerial discretion while non-discretionary accruals of expected level of accruals in the firm provided there have no manipulation of earnings. Stock price-based incentives in the form of stock-based compensation and share ownership mitigate this disclosure agency problem. A positive relationship is found between discretionary accruals and the governance index. There is evidence of pervasive income smoothing, which improves the persistence and predictability of reported earnings.

For future research, the researcher must find the external aspect causing the accrual discretion to be done by the manager. Not only looking from the aspect of manager's interests in, but how the discretionary accruals in the financial statements are able to influence the users of financial statement information.

\begin{tabular}{|c|c|c|}
\hline No. & Source & Relationship \\
\hline 1 & Teoh et al. (2008) & $\begin{array}{l}\text { Companies that conduct IPOs report higher earnings during the } \\
\text { IPO by reporting aggressive abnormal accruals }\end{array}$ \\
\hline 2 & Bernard and Skinner (1996) & $\begin{array}{l}\text { Accrual accounting choices by managers are opportunistic and } \\
\text { reflect other information }\end{array}$ \\
\hline 3 & Khalil and Simon (2015) & Institutional ownership affects the accrual discretion \\
\hline 4 & Huang et al. (2006) & $\begin{array}{l}\text { Managers tend to behave opportunistically to maximize their } \\
\text { interests at the expense of others }\end{array}$ \\
\hline 5 & Dechow et al. (2012) & $\begin{array}{l}\text { Characteristics of the company as an instrument of } \\
\text { measurement of accrual quality, shows that the accrual quality } \\
\text { is positively related to the persistence of the manager's } \\
\text { earnings behavior }\end{array}$ \\
\hline 6 & Mey and de Klerk (2015) & $\begin{array}{l}\text { Accrual quality gets better when the CEO is a Chartered } \\
\text { Accountant }\end{array}$ \\
\hline 7 & Bergstresser and Philippon (2006) & $\begin{array}{l}\text { The use of accrual discretion in reporting more severe earnings } \\
\text { occurs in companies where the total of CEO's comparisons is } \\
\text { more closely tied to share value and stock ownership options }\end{array}$ \\
\hline 8 & Ashley et al. (2012) & $\begin{array}{l}\text { The high earnings persistence increases the manager's chances } \\
\text { of increasing salary and bonus compensation }\end{array}$ \\
\hline 9 & Sweeney (1994) & $\begin{array}{l}\text { Companies that have high debt levels tend to respond with } \\
\text { changes in accounting revenues }\end{array}$ \\
\hline 10 & Koerniadi and & Managers simultaneously use the accrual discretion and \\
\hline & Tourani-Rad (2011) & $\begin{array}{l}\text { dividend changes in communicating company information } \\
\text { about future profitability to the market }\end{array}$ \\
\hline 11 & Alali (2011) & $\begin{array}{l}\text { The influence of Cash Flow Operation mediation variation } \\
\text { between the accrual discretion in financial report with audit fee }\end{array}$ \\
\hline
\end{tabular}

$$
\text { influence the users of financial statement information. }
$$

Table 1.

Relationship between Discretionary

Accrual and Opportunistic Manager 


\begin{tabular}{|c|c|c|c|c|c|c|c|c|}
\hline Source & Compensation & $\begin{array}{c}\text { Debt } \\
\text { Covenant }\end{array}$ & $\begin{array}{l}\text { Fee } \\
\text { Audit }\end{array}$ & $\begin{array}{l}\text { Anteceden } \\
\text { Ownership } \\
\text { Structure }\end{array}$ & Profitability & $\begin{array}{l}\text { Return } \\
\text { Stock }\end{array}$ & $\begin{array}{c}\text { Sentiment } \\
\text { Investor }\end{array}$ & $\begin{array}{r}\text { Discretionary } \\
\text { Accrual in }\end{array}$ \\
\hline $\begin{array}{l}1 \text { Healy (1985) } \\
2 \text { Izadi Zadeh Darjezi } \\
\text { (2016) }\end{array}$ & $\begin{array}{l}-1 \\
\checkmark\end{array}$ & & & & & & & Statement \\
\hline $\begin{array}{l}3 \text { Khalil and Simon } \\
\text { (2014) }\end{array}$ & $\checkmark \mathrm{v}$ & $\checkmark \mathrm{v}$ & & $\checkmark \mathrm{v}$ & $\checkmark \mathrm{v}$ & & & 59 \\
\hline $\begin{array}{l}4 \text { Herda et al. (2014) } \\
5 \text { Sweeney (1994) }\end{array}$ & & $\begin{array}{ll}\checkmark & \mathrm{v} \\
\mathcal{J} & \mathrm{v}\end{array}$ & & & & & & \\
\hline 6 Balsam (1998) & $\checkmark \mathrm{v}$ & & & & & & & \\
\hline 7 Gul et al. (2003) & $\checkmark \mathrm{v}$ & & $\checkmark \mathrm{v}$ & & & & & \\
\hline $\begin{array}{l}8 \text { Koerniadi and Tourani- } \\
\operatorname{Rad}(2011)\end{array}$ & & & & & $\checkmark \mathrm{v}$ & $\checkmark \mathrm{v}$ & $\checkmark \mathrm{v}$ & \\
\hline 9 Hribar et al. (2017) & & & & & $\checkmark \mathrm{v}$ & $\checkmark \mathrm{v}$ & $\checkmark \mathrm{v}$ & \\
\hline $\begin{array}{l}10 \text { Mosebach and Simko } \\
\text { (2010) }\end{array}$ & $\checkmark \mathrm{v}$ & & & & $\checkmark \mathrm{v}$ & $\checkmark \mathrm{v}$ & & \\
\hline 11 Linck et al. (2013) & & & & & $\checkmark \mathrm{v}$ & $\checkmark \mathrm{v}$ & & \\
\hline $\begin{array}{l}12 \text { Khan and Mather } \\
\text { (2013) }\end{array}$ & $\checkmark \mathrm{v}$ & & & $\checkmark \mathrm{v}$ & $\checkmark \mathrm{v}$ & & & $\begin{array}{r}\text { Table } 2 . \\
\text { Antecedents of }\end{array}$ \\
\hline 13 Hribar et al. (2007) & & & & & $\checkmark \mathrm{V}$ & & $\checkmark \mathrm{v}$ & Discretionary \\
\hline 14 Demirkan et al. (2009) & & $\checkmark \mathrm{v}$ & & & $\checkmark \mathrm{v}$ & $\checkmark \mathrm{v}$ & & Accrual \\
\hline
\end{tabular}

\section{References}

Ashley, Allan S, Yang, Simon S.M. (2004). Executive Compensation and Earnings Management, Journal of Business Ethics 50, 4; Arts \& Humanities Database pg. 369.

Agnes Cheng, C.S. and Reitenga, A. (2009). "Characteristics of Institutional Investors and Discretionary Accruals". International Journal of Accounting \& Information Management, Vol. 17, No. 1, pp. 5-26.

Alali, F. (2011). "Audit Fees and Discretionary Accruals: Compensation Structure Effect”. Managerial Auditing Journal, Vol. 26, No. 2, pp. 90-113.

Ashley, Allan S; Yang, Simon S M (2004). Executive Compensation and Earnings Management, Journal of Business Ethics 50, 4; Arts \& Humanities Database pg. 369.

Baber, W.R. and Fairfield, P.M. (1991). "The Effect of Concern about Reported Income on Discretionary Spending Decisions: The Case of Research and Development”. Accounting Review, Vol. 66, No. 4, pp. 818-829.

Balsam, S. (1998). "Discretionary Accounting Choices and CEO Compensation". Contemporary Accounting Research, Vol. 15, No. 3, pp. 229-252.

Barth, M.E., Cram, D.P. and Nelson, K.K. (2001). "Accruals and the Prediction of Future Cash Flows". Accounting Review, Vol. 76, No. 1, pp. 27-58.

Bergstresser, D. and Philippon, T. (2006). "CEO Incentives and Earnings Management". Journal of Financial Economics, Vol. 80, No. 3, pp. 511-529.

Bernard, V.L. and Skinner, D.J. (1996). "What Motivates Managers' Choice of Discretionary Accruals?”. Journal of Accounting and Economics, Vol. 22 (November 1995), pp. 313-325.

Bonazzi, L. and Islam, S.M.N. (2007). "Agency theory and corporate governance". Journal of Modelling in Management, Vol. 2, No. 1, pp. 7-23.

Dechow, P., Hutton, A., Kim, J.H. and Sloan, R.G. (2012). "Detecting Earnings Management: A New Approach”. Journal of Accounting, Vol. 50 (April 2011), pp. 275-334. 
Proceedings of MICoMS 2017

\section{0}

Demirkan, S. and Platt, H. (2009). "Financial Status, Corporate Governance Quality, and the Likelihood of Managers Using Discretionary Accruals”. Accounting Research Journal, Vol. 22, No. 2, pp. 93-117.

Demirkan, S., Radhakrishnan, S. and Urcan, O. (2012) "Discretionary Accruals Quality, Cost of Capital, and Diversification”. Journal of Accounting, Auditing \& Finance, Vol. 27, No. 4, pp. 496-526.

Frugier, A., Ding, Z., Liu, Z., Zhang, Y.Y.Y., Long, R., Guo, K., ... Wurgler, J. (2016). "Investor Sentiment, Customer Satisfaction and Stock Returns". Journal of Banking and Finance, Vol. 21, No. 1, pp. 75-94.

Gul, F.a, Chen, C.J.P. and Tsui, J.S.L. (2003). "Discretionary Accounting Accruals, Managers' Incentives, and Audit Fees". Contemporary Accounting Research, Vol. 20, No. 3, pp. 441-464.

Healy, P.M. (1985). "The Effects of Bonus Scheme on Accounting Decisions”. Journal of Accounting \& Economics, Vol. 7, pp. 85-107.

Herda, D.N., Notbohm, M.A. and Dowdell, T.D. (2014). "The Effect of External Audits of Internal Control over Financial Reporting on Financial Reporting for Clients of Big 4, Second-tier, and Small Audit Firms”. Research in Accounting Regulation, Vol. 26, No. 1, pp. 98-103.

Hribar, P., Melessa, S.J., Small, R.C. and Wilde, J.H. (2017). "Does Managerial Sentiment Affect Accrual Estimates? Evidence from the Banking Industry". Journal of Accounting and Economics, Vol. 63, No. 1, pp. 26-50.

Huang, P., Louwers, T. J., Moffitt, J. S., \& Zhang, Y. (2008). Ethical management, corporate governance, and abnormal accruals. Journal of Business Ethics, 83(3), 469-487.

Izadi Zadeh Darjezi, J. (2016). "The Role of Accrual Estimation Errors to Determine Accrual and Earnings Quality". International Journal of Accounting \& Information Management, Vol. 24, No. 2, pp. 98-115.

Kamarudin, K.A. and Ismail, W.A.W. (2014). "The Risk of Earnings Quality Impairment”. ProcediaSocial and Behavioral Sciences, Vol. 145, pp. 226-236.

Khalil, M. and Simon, J. (2014). "Efficient Contracting, Earnings Smoothing and Managerial Accounting Discretion". Journal of Applied Accounting Research, Vol. 15, No. 1, pp. 100-123.

Khan, A. and Mather, P. (2013). "The Value of Executive Director Share Ownership and Discretionary Accruals". Accounting Research Journal, Vol. 26, No. 1, pp. 35-55.

Khan, M. and Watts, R.L. (2009). "Estimation and Empirical Properties of a Firm-Year-Measure of Accounting Conservatism”. Journal of Accounting \& Economics, Vol. 48, Nos. 2-3, pp. 132-150.

Koerniadi, H. and Tourani-Rad, A. (2011). "The Role of Accruals as a Signal in Earnings and Dividend Announcements: New Zealand Evidence". Journal of Applied Accounting Research, Vol. 12, No. 2, pp. 108-122.

Linck, J.S., Netter, J. and Shu, T. (2013). "Can Managers Use Discretionary Accruals to Ease Financial Constraints? Evidence from Discretionary Accruals Prior to Investment”. Accounting Review, Vol. 88, No. 6, pp. 2117-2143.

Mey, E. and de Klerk, M. (2015). "Association between Having a CA(SA) as CEO and Accruals Quality”. Meditari Accountancy Research, Vol. 23, No. 3, pp. 276-295.

Mosebach, M. and Simko, P. (2010). "Discretionary Accruals and the Emergence of Profitability". Journal of Accounting, Auditing and Finance, Vol. 25, No. 3, pp. 351-374.

Sweeney, A.P. (1994). "Debt Covenant Violations Accounting Responses and Managers". Journal of Accounting and Economics, Vol. 17, pp. 281-308.

\section{Corresponding author}

Muhammad Haykal can be contacted at mhaykal@unimal.ac.id 